\title{
A FAST PROCEDURE AS AN ACCESS TO JUSTICE IN ORDER TO REALIZE A SIMPLE, FAST, AND LOW COST PRINCIPLE IN INDONESIA
}

\author{
Anita Afriana and Efa Laela Fakhriah \\ Faculty of Law, Universitas Padjadjaran \\ E-mail: nie782003@yahoo.com
}

\begin{abstract}
Civil disputes resolution in court has complicated procedures. For the parties with small value of claims, the settlement through the court with a convoluted procedure is not an appropriate choice because time spent in the court is not comparable to the value of the dispute. On the other hand, the settlement by arbitration and alternative dispute resolution sometimes considered insufficient to provide legal certainty. The objective of this article is to analyze fast procedures that are used in the settlement of a lawsuit simply as a means of access to justice, and the prospects of fast procedures in the civil judicial system of Indonesia. The approach used is normative juridical. The results shows that the regulation of fast procedures in indonesia is an advancement as a means of access to justice but it still required socialization to the public about fast procedure and simple lawsuit.
\end{abstract}

Keywords: access to justice, fast procedures, simple lawsuit, private dispute

\begin{abstract}
Abstrak
Penyelesaian sengketa perdata di pengadilan sarat dengan prosedur acara. Bagi pihak bersengketa dengan nilai gugatan kecil, pengadilan bukanlah pilihan tepat untuk menyelesaikan sengketa karena waktu untuk beracara tidaklah sebanding dengan besarnya nilai yang disengketakan. Sementara, penyelesaian melalui lembaga non litigasi kadangkala tak cukup memberikan kepastian hukum. Dengan pendekatan yuridis normatif, tulisan ini membahas acara cepat dalam penyelesaian gugatan sederhana sebagai sarana access to justice, dan prospek acara cepat dalam sistem peradilan perdata Indonesia. Berlakukannya acara cepat di Indonesia merupakan suatu kemajuan sebagai sarana access to justice untuk terwujudnya asas sederhana, cepat, biaya ringan. Dengan mekanisme Small Claims Court, acara cepat yang diatur dalam PerMa No. 2 Tahun 2015 dapat mempercepat proses dan bermanfaat bagi masyarakat sebagai sarana penyelesaian sengketa yang efektif agar terwujud peradilan yang dilaksanakan dengan asas sederhana, cepat, dan biaya ringan, akan tetapi disarankan masih perlunya sosialisasi tentang prosedur acara cepat dan gugatan sederhana pada masyarakat.
\end{abstract}

Kata kunci: akses terhadap keadilan, acara cepat, gugatan sederhana, sengketa perdata.

\section{Introduction}

Based on the 1945 Constitution of the Republic of Indonesia, the Judicial power in Indonesia is carried out by the Supreme Court and judicial bodies underneath, to organize the judiciary to enforce the law and justice. That justice called as the last resort in resolving disputes, although the courts is not the only way that can be through to resolve the dispute. ${ }^{1}$

Sufiarina and Efa Laela Fakhriah, "Kewajiban Upaya Non Adjudikasi Sebagai Syarat Mendaftarkan Gugatan Guna Mewujudkan Peradilan Sederhana, Cepat, dan Biaya Ringan (Tinjauan atas Perma No. 1 Tahun 2008)", Jurnal Padjadjaran Ilmu Hukum, Vol. 1 No. 1, April
Inline with the applicable of law, the only official institution which is the executor of judicial power in Indonesia to examine and decide both criminal cases and civil is the General Courts, in this case is the District Court based on Article 2 (4) of Law No. 48 Year 2009 concerning Judicial Authority (here-inafter referred to UUKK) stated that justice is done with a simple, fast, and low cost.

2014, Bandung: Law Faculty, Universitas Padjadjaran, page 117. 
A fast, simple, and low cost principle of justice is clearly stated in Article 2 (4), and Article 4 (2) Judicial Authority Law, also in the Supreme Court Circular (SEMA) No. 2 Year 2014 concerning the Settlement of the Case in the First Level and appeal in 4 (Four) courts. Through this SEMA urged to the first court instance and the appeal to be able to resolve the dispute within a maximum of five months, however, in practice it is not uncommon to a dispute disconnected after exceeding 50 days with a variety of factors. Meanwhile through the mediation procedure in the courts should be able to accelerate the settlement of civil disputes through mediation (peace) without the need to continue the settlement through civil judicial mechanism, but the fact of the mediation process often fail to reconcile the parties. ${ }^{2}$ Implementation of mediation in courts still seem formalistic, resulting in a civil case. ${ }^{3}$

The settlement of disputes through non litigation (by peaceful) on the other hand, based on the agreement of the parties, but the result does not have the power of binding formal for the parties, even the law requires that the parties' agreement are set forth in the deed written and registered to District Court. In addition, in the system of civil procedural law applicable, that the deed of the agreements that have been achieved can not be directly applied to the court to be the decision of the peace judge (acta van Dading), but the parties must still file a lawsuit to the court by attaching deed agreement referred to and then disconnected in proceedings under the deed of peace that has been achieved by the parties outside the court, with the decision of the judge of peace (acta van Dading).

The other way of non-litigation dispute resolution is through the arbitration that is

Candra Irawan, "Problematika Penerapan Peraturan Mahkamah Agung Republik Indonesia Nomor 1 tahun 2008 dalam Penyelesaian Sengketa Perdata di Indonesia", Hukum Acara Perdata Jurnal ADHAPER, Vol. 1 No. 2, July-December 2015, Bandung: Association of Civil Court Lecturer, page 62

3 Rahadi Wasi Bintoro, "Implementasi Mediasi litigasi Di Lingkungan Yurisdiksi Pengadilan Negeri Purwokerto", Jurnal Dinamika Hukum, Vol. 14 No.1, January 2014, Purwokerto: Law Faculty, Universitas Jenderal Soedirman, page. 13 meant to be judicial (through the judicial process) even though the arbitration is not a judicial body but a dispute resolution institutions. In practical, through the arbitration institution also often do not reach the settlement of disputes effectively and efficiently, because even there has been a clear regulations on competence to hear the absolute between a court of arbitration, the disputing parties are often still submit the dispute to the court and the court examine and decide upon the case, therefore dispute settlement becomes effective and more efficient. ${ }^{4}$

The process which implemented until now is that HIR and or RBg not distinguish the judicial procedure based on the size of the value of the lawsuit, in other words in the judicial system civil law is based on the provisions of HIR and or RBg the settlement is done without further distinguish the amount of value claim and simple absence of proof. In practice, it often completing a litigation State require a long time, the more the longer it takes when there are those who propose remedies. This condition is not in line with the principle of justice that is fast, simple, and low cost as mandated by UUKK. For justice seekers who suffered a small loss but wanted to defend their rights in the event of disputes, the settlement through non-litigation forum is not the right choice too, as well as resolve the disputes through litigation with long procedures are often considered to be disproportionate to the value of the relative small lawsuit.

Therefore, with the development of legal relations in the other economic and civil side in the community needed the dispute settlement procedure that is easier, faster, so the cost is also lightweight, especially in a simple legal relationship, therefore on August 7 in 2015 the Supreme Court issued PerMa No. 2 In 2015 concer-ning Procedures of Simple Action Settlement. Artcle 1 PerMa No. 2 of 2015, mentions that the lawsuit settlement is a simple proce-

\footnotetext{
4 Efa Laela Fakhriah, "Mekanisme Small Claims Court dalam Mewujudkan Tercapainya Peradilan Sederhana, Cepat, dan Biaya Ringan," Jurnal Mimbar Hukum, Vol. 25 No. 2, June 2013, Yogyakarta: Law Faculty, Universitas Gadjah Mada, page 259.
} 
dure of examination in the trial of a civil suit with the suit material value of $R p 200,000,000$. 00 (two hundred million rupiahs) which was completed with the simple procedures and proof.

Rapid settlement of civil disputes in the District Court urgently needed in Indonesia, considering the huge number of people so that the tendency of disputes is also high. According to Takdir Rahmadi, the other reason is the fast inspection will reduce the accumulation of matter at both the District Court, High Court, and the Supreme Court, as well as reasons - other reasons, namely: first, the principle of judicial to realize a fast, simple, and the low cost; second, the prevailing legal proceeding is still not meet the cost of justice: a very complicated and long winded; and third, prevent the vigilante. ${ }^{5}$

Some countries with a common law background, developing the methods of dispute resolution called the Small Claims Court (hereinafter abbreviated to SCC). SCC Model is a dispute resolution system that is simple, with a single judge, without a jury, and the proof is simple. In addition to the United States, SCC also applied among others in India, New Zealand, Hong Kong, Singapore, and Japan. In these countries, the presence of SCC is considered as effective enough to resolve the dispute with a small loss quickly and efficiently. ${ }^{6}$ Fast events that are used to settle a lawsuit simple as stipulated in PerMA No. 2 of 2015 has the same concept with the SCC. The implementation of proceeding, then the philosophy will give you access to justice.

The ease of public access to justice can in fact be realized, among others, with their facilities and adequate infrastructure, from the courthouse accessible, the "friendly" building arrangement, the number of officers fairly and professionally, and choices of methods of sol-

5 Anita Afriana, "Penerapan Acara Singkat dan Acara Cepat Dalam Penyelesaian Sengketa Perdata di Pengadilan: Suatu Tinjauan Politik Hukum Acara Perdata", Jurnal Hukum Acara Perdata ADHAPER, Vol. 1 No. 1, January-June 2015, Bandung: Association of Civil Court Lecturer, page 40.

6 Ibid, page 34. ving problems and even availability container to mind if people are not satisfied with the performance of existing institutions, therefore introduced and the regulation of fast events as a method of dispute resolution for the lawsuit is simply the concrete steps in order to realize the principle of quick, simple, and inexpensive, and is an important strategy in strengthening public access to justice in Indonesia, not least because Indonesia has declared itself as a state of law (Article 1 (3) The 1945 Constitution of the Republic of Indonesia).

\section{Discussion}

Fast Procedure Mechanisms As An Access to Justice in Civil Dispute Resolution.

One important issue for a future development of the law, including the law enforcement in Indonesia is how to carry out the judicial authorities in accordance with the 1945 Constitution of Republic of Indonesia and UUKK. ${ }^{7}$ The rule of law through the administration of justice as a means to ensure a fair process in order to produce a decision that takes into account the interests (of justice) by both parties. The purpose of all the systems in the judicial procedure is to achieve justice, albeit with different methods. Fast events that are used to settle a lawsuit simple, in other countries either applying civil law and common law known as SCC with slightly different characteristics from one another, but the purpose is the same, namely that carried to obtain access to justice.

SCC concept is intended to provide a quick and economical solution to resolve disputes that do not require an expensive cost. Each court is committed to resolve disputes effectively and fairly with upholding the rule of law and improving access to justice.

Justice is the ideals and purposes of the law are realized through the law. ${ }^{8}$ Access to

Fence M. Wantu, "Kendala Hakim dalam Menciptakan Kepastian Hukum, Keadilan, dan Kemanfaatan di Peradilan Perdata", Jurnal Mimbar Hukum, Vol. 25 No. 2, June 2013 Edition, Yogyakarta: Law Faculty, Universitas Gadjah Mada, page 206.

8 Inge Dwisvimiar, " Keadilan dalam Perspektif Filsafat Ilmu Hukum”, Jurnal Dinamika Hukum, Vol. 11 No. 3, September 2011, Purwokerto: Law Faculty, Universitas Jenderal Soedirman, page 502. 
justice is a fundamental right (core) and a central concept in the broader field than just justice. The content and unlimited in scope and covers only the recognition of the rights and legal knowledge, but also extends to the same access to all the mechanisms of a fair trial, impartial and speed in resolving disputes; the availability of information relating to the rights in the judicial system of the judiciary and court decisions. A debate among legal experts the world that need to change procedures (procedural rules) relating to the cost factor and the efficiency of dispute resolution in the courts to achieve access to justice. ${ }^{9}$

The focus of access to justice has evolved, at first access to justice only emphasize efforts to provide legal aid for the poor, then develops into a union of interests of the parties involved in providing access to justice for the poor, with a concept which focuses on the basic purpose of existence a legal system. The next development is on measures to support the ongoing reforms to achieve greater goals again that revamping the legal system to achieve the ideal form of state law. ${ }^{10}$

Annual Report on the Supreme Court in 2013 pages $80-86$, it can be concluded that the policy of access to justice among others ${ }^{11}$. First, policy changes legal services for the underprivileged in court: fee waiver, the Legal Aid Post, the trial outside the courthouse. Second, mediation. Third, integrated services, the right to legal identity. Fourth, the mecanism of Small Claims resolution. In harmony with the policy of access to justice, required legal and judicial reform strategy more comprehensively and systematically, which is intended to allow people to get justice one of them through the civil justice system reform, namely the introduction of fast events.

\footnotetext{
Ross Craston, 2004, The Rational Study of Law:Social Research and Access To Justice, Oxford: Oxford University Press, p. 34.

10 Anita Afriana, "Towards Access To Justice: Quick Procedures In Civil Dispute Settlement In Indonesia", Paper on International Conference Access To Justice, Malang: $21^{\text {st }}$ November 2015, conducted by Law Faculty of Universitas Brawijaya, page 6 .

11 Ibid, page 7
}

The fast even are used to check for simple claims is a big step from the Supreme Court in the renewal of the civil justice system for fast events have never known and preconfigured in HIR and RBg. Speed means of dispute resolution will bring benefits to all sections of society to access justice in a fast, simple for a small cost.

The Prospects of Fast Procedure Implementation In Justice System in Indonesia by PerMa No. 2 Year 2015

Humans as social beings need social interaction with one another. Their interests in such interactions can lead to conflict. Conflicts can not be resolved will develop into disputes that arise due to various reasons and problems that lie behind them, mainly because of the conflict of interest between the parties. Proceedings in court is a series of long, starting from the first trial, appeal, appeal, and reconsideration, make a settlement takes a long time, when people are looking for the settlement process is easy and fast, so it is necessary make judicial system designed effective and efficient. ${ }^{12}$

Indeed, the focus of dispute resolution is the speed (time) settlement. Good settlement of civil disputes through non litigation and litigation, to be fast examination time, but the judiciary is loaded with procedural mechanism which is a formal juridical provisions that can not be remained unfulfilled. Settlement of civil disputes in court using civil law which is binding and force, the provisions and principles applicable in civil procedure law also binding and can not be criss, among others, the first principle is important is justice done fast, simple, and low cost.

Unimplementation of the fast principle in dispute resolution, causing the cost borne by

\footnotetext{
12 Anita Afriana, “Penerapan Peraturan PerMA No. 1 Tahun 2008 Tentang Prosedur Mediasi di Pengadilan dalam Praktik di Pengadilan Negeri Bandung”, Jurnal Kajian Hukum Al-ADALAH, Vol. 7 No. 1, June 2008, Lampung: Law and Syari'ah Faculty, IAIN Raden Intan Lampung, page 2.
} 
the justice seekers increased and swollen, ${ }^{13}$ though it is to maintain law is being violated by the courts in principle be charged include the cost of secretariat and summonses, notices of the parties, as well as stamp duty, ${ }^{14}$ plus more psychological burden due to the length obtain legal certainty via decision. For his own court, the settlement of a case of time will affect the administrative order of the court which caused the number of stacking and delinquency cases.

Given the high number of disputes that go to trial and their legal remedies as a form of dissatisfaction with the court decision, among others deemed to be incompatible if earmarked for the settlement of disputes with a value of small claims, it should be pursued effective mechanisms at the first level and the form of its legal efforts. Based on that, right when in Indonesia currently has a mechanism of fast events are arranged in a simple Perma to settle a lawsuit that primarily emphasizes speed turnaround time with events and different stages with the usual procedure, which is known. Therefore, the civil justice system in Indonesia currently imposes fast events to examine and decide upon a simple civil disputes as stipulated in Perma No. 22015.

The existence of fast events that are used to examine the lawsuit simple to bridge between the settlement of disputes through non litigation that the results do not buck up binding to the settlement of litigation more legal certainty, in order to obtain a dispute settlement mechanism that is fast, simple, and inexpensive with the decision have the power of binding with procedural mechanism separate from the case investigation is kontradiktoir (regular). Events quickly used in checking the lawsuit simple imposes limits examination period is a maximum of 25 days from the first day of the

13 I Ketut Tjukup, et.all "Penerapan Teori Hukum Pembangunan dalam Mewujudkan Peradilan Sederhana, Cepat dan Biaya Ringan", Jurnal Hukum Acara Perdata ADHA$P E R$, Vol 1 No. 1, January-June 2015, Bandung: Association of Civil Court Lecturer, page 145.

14 Tata Wijayanta, "Bantuan Hukum Golongan Tidak Mampu Dalam Perkara Perdata di Pengadilan Negeri Yogyakarta", Jurnal Mimbar Hukum, Vol. 24 No. 1, February 2012, Yogyakarta: Law Faculty, Universitas Gadjah Mada, page 111. trial. This rapid period of time the parties were not given the opportunity to file claims provisions, exceptions, reconventions, intervention, replict, closing argument, or conclusions (Article 17).

A simple Lawsuit change to be the judicial competence of the country. Implementation of competence was realized by the judge assigned to examine, hear and decide cases brought before it. ${ }^{15}$ Not all cases can be solved with a simple lawsuit. Perma No. 2 In 2015 determining the civil suit can be categorized as simple lawsuit. First, the dispute in default/ breach of contract and or the action against law with the maximum value of 200 million. Second, the case is not included in the competence of special courts. Third, its not the disputes over land rights. Plaintiffs and Defendants each no more than one, unless they have the same legal interest. Fourth, the Defendant's residence must be known. Fifth, plaint and defendant must be domiciled in the same court of law.

Those are cumulative requirements. If one of the conditions above are not met, then the case can not be solved with a quick event. The existence of procedural mecha-nisms that have event procedures quickly, it will be many disputes are handled quickly by a simple verification in court.

The existence of fast events/SCC is intended to improve access to justice by providing services that are fast, cheap, and fair. Allegedly high legal costs can be a barrier to justice, especially in a simple suit. Events quickly as the mechanism of settlement of civil disputes in court for a lawsuit by a small value very efficient and effective, then through the mechanism of fast events meruapakan one of supporting the achievement of the principles of justice that is simple, fast, and inexpensive as stated in law and expected by the justice seeker.

15 Eman Suparman, "Perkembangan Doktrin Penyelesaian Sengketa di Indonesia", Jurnal Penegakan Hukum, July 2006, Vol. 3 No. 2, Bandung: Civil Court Department of Law Faculty, Universitas Padjadjaran, page 25. 


\section{Conclusion}

Practice settlement of civil disputes in court often takes a long time to obtain a decision. By mechanisms that long and not simple, it is not very profitable for the parties, especially for disputes with a value of small claims. In harmony with the development of legal relations in the economic and other civil society needed dispute settlement procedure more simple, fast and low cost, especially in a legal relationship that is simple. Therefore, through a PerMa No. 22015 Concerning Procedures Simple Action Settlement is finalized with fast events easier for people to get justice (access to justice). The mechanism of fast events suspected as measures to encourage the acceleration of economic growth in Indonesia to speed up dispute resolution and is able to provide benefits to the community to get the means of dispute resolution that is efficient and effective in order to create justice implemented the principle of simple, fast, and inexpensive as stated in Act OF and expected by the community as justice seeker.

\section{Suggestion}

Based on the problems and discussion, some suggestions are given, namely: first the fast events procedure in the examination of claims will simply be able to increase public confidence in the judiciary as a means of obtaining justice, therefore, the court needs to socialize quick procedure for simple contested to the society as justice seeker. Second, the setting of fast events in PerMa is thought to reduce the buildup of matter and fill the legal vacuum, but ideally expected future arrangements regarding the event can quickly be loaded in the Law of Civil Procedure of the National, which is still in draft form (RUU).

\section{Reference}

Afriana, Anita. "Penerapan Peraturan PerMA No. 1 Tahun 2008 Tentang Prosedur Mediasi di Pengadilan dalam Praktik di Pengadilan Negeri Bandung". Jurnal Kajian Hukum Al-ADALAH, Vol. 7 No. 1 June 2008. Lampung: Law \& Syari'ah Faculty, IAIN Raden Intan Lampung;
..--.-. "Penerapan Acara Singkat dan Acara Cepat Dalam Penyelesaian Sengketa Perdata di Pengadilan: Suatu Tinjauan Politik Hukum Acara Perdata". Jurnal Hukum Acara Perdata ADHAPER, Vol. 1 No. 1 July-December 2015. Bandung: Association of Civil Court Lecturer;

-...-... "Towards Access To Justice: Quick Procedures In Civil Dispute Settlement In Indonesia", Paper on International Conference Access To Justice, Malang: $21^{\text {st }}$ of November 2015, conducted by Law Faculty of Universitas Brawijaya;

Bintoro, Rahadi Wasi. "Implementasi Mediasi litigasi di Lingkungan Yurisdiksi Pengadilan Negeri Purwokerto". Jurnal Dinamika Hukum. Vol. 14 No. 1 January 2014. Purwokerto: Law Faculty, Universitas Jenderal Soedirman;

Craston Rose. 2004. The Rational Study of Law: Social Research and Access To Justice. Oxford: Oxford University Press;

Dwisvimiar, Inge. "Keadilan dalam Perspektif Filsafat Ilmu Hukum". Jurnal Dinamika Hukum, Vol. 11 No. 3 September 2011. Purwokerto: Law Faculty, Universitas Jenderal Soedirman;

Fakhriah, Efa Laela. "Mekanisme Small Claims Court Dalam Mewujudkan Tercapainya Peradilan Sederhana, Cepat, dan Biaya Ringan". Jurnal Mimbar Hukum, Vol. 25 No. 2. June 2013. Yogyakarta: Law Faculty, Universitas Gadjah Mada;

Irawan Candra. "Problematika Penerapan Peraturan Mahkamah Agung Republik Indonesia Nomor 1 tahun 2008 dalam Penyelesaian Sengketa Perdata di Indonesia". Hukum Acara Perdata Jurnal ADHAPER, Vol. 1 No. 2, July-December 2015. Bandung: Association of Civil Court Lecturer;

Wantu, Fence M. "Kendala Hakim dalam Menciptakan Kepastian Hukum, Keadilan, dan Kemanfaatan di Peradilan Perdata". Jurnal Mimbar Hukum, Vol 25 No. 2 June 2013. Yogyakarta: Law Faculty, Universitas Gadjah Mada;

Sufiarina dan Efa Laela Fakhriah. "Kewajiban Upaya Non Adjudikasi sebagai Syarat Mendaftarkan Gugatan guna Mewujudkan Peradilan Sederhana, Cepat, dan Biaya Ringan (Tinjauan atas Perma No. 1 Tahun 2008)". Jurnal Padjadjaran Ilmu Hukum, Vol. 1 No. 1, April 2014. Bandung: Law Faculty, Universitas Padjadjaran; 
Suparman, Eman. "Perkembangan Doktrin Penyelesaian Sengketa di Indonesia". Penegakan Hukum Jurnal, July 2006. Vol. 3 No. 2. Bandung: Civil Court Department. Law Faculty, Universitas Padjadjaran;

Tjukup, I Ketut; et.all. "Penerapan Teori Hukum Pembangunan dalam Mewujudkan Peradilan Sederhana, Cepat dan Biaya Ringan". Jurnal Hukum Acara Perdata ADHAPER, Vol. 1 No. 1. January-June 2015. Bandung: Association of Civil Court Lecturer;

Wijayanta, Tata. "Bantuan Hukum Golongan Tidak Mampu Dalam Perkara Perdata di Pengadilan Negeri Yogyakarta". Jurnal Mimbar Hukum, Vol. 24 No. 1. February 2012. Yogyakarta: Law Faculty, Universitas Gadjah Mada. 